A paper by J. W. Jordan, of the Mellon Institute, Pittsburgh, was presented by $\mathbf{R}$. E. Grim. It described the alteration of bentonite to a condition in which it is compatible with liquid amines. Thixotropic organic gels have been prepared in this manner.

In the last session P. Gallitelli (Italy) described the formation in nature of a kaolinitic clay (containing some mica) from diabase. Experiments on the decomposition of diabase on a laboratory scale, by the percolation of $\mathrm{CO}_{2}$-charged water, both at normal and elevated temperature and pressure, have shown the same minerals to be formed.

D. M. C. MacEwan described the formation in a Scottish soil derived from norite of a trioctahedral montmorillonite, by alteration of flakes of a biotitic mineral. The montmorillonite occurs as stable secondary aggregates, which are pseudomorphs after the original material, and account for the high base exchange capacity of the sand and silt.

J. E. Hemingway and G. W. Brindley described the occurrence of dickite as a replacement mineral in Middle Jurassic rocks of N.E. Yorkshire, an occurrence which they consider invalidates the view that dickite is necessarily of hydrothermal origin, and indicates its migration in solution.

All the papers gave rise to lively discussion, and the exchange of views was universally felt to be valuable. Considering the specialized nature of the subject-matter, the meetings were well attended. The Chairmen at the various meetings were as follows :-

First Session . Dr. G. W. Brindley (Chairman of the Clay Minerals Group) and Dr. S. Hénin (France). Second Session . Professor R. E. Grim (U.S.A.) and Professor J. J. de Lange (Netherlands).

Third Session . Dr. W. Campbell Smith (President of the Mineralogical Society) and Dr. J. S. Hosking (Australia).

\title{
ANNOUNCEMENT
}

\section{UNIVERSITY OF LONDON : SPECIAL UNIVERSITY LeCTURES IN GEOLOGY}

The Academic Registrar announces that two lectures will be given at University College (Gower Street, W.C. 1) by Professor G. DeLÉPINE at 5.30 p.m. on 8th and 10th March, 1949 . Admission free, without ticket.

Lecture 1: Comparative Stratigraphy of the Carboniferous Marine Formations in N.W. Europe and Mediterranean Area.

Lecture 2: Movements of the late Palaeozoic Seas-Devonian and Carboniferous-in W. Europe and N. Africa. 